Tér és Társadalom 16. évf. 2002/1. 135-159. p.

Tér és Társadalom

XVI. évf. 2002

1: $135-159$

\title{
VERSENYKÉPESSÉG
}

\section{GONDOLATOK A KÖZLEKEDÉS SZEREPÉRŐL A RÉGIÓK/VÁROSOK VERSENYKÉPESSÉGÉNEK ALAKULÁSÁBAN}

\section{(Thoughts on the Role of Transportation in the Formation of the Competitiveness of Region/Cities)}

\section{ERDÖSI FERENC}

Kulcsszavak:

közlekedés versenyképesség régió regionális közlekedés

Miután a regionális közlekedés alatt a tértudományok és a közlekedéstudományok müvelöi meglehetösen eltérö fogalmakat értenek, mindenekelött bemutatjuk, hogy véleményink szerint mi is valojában a regionális közlekedés.

Fejlödésünk jelenlegi fázisában, amikor az ország mielöbbi talpra allitísa érdekében a killföldi tôke beáramoltatására törekvés és a külpiacokra orientálódás az elsödleges szempont, érthetö módon a régiók külsö közlekedési kapcsolatainak javítása került a figyelem központjäba, és a térségek gazdasági aktorai számára egyelöre csak alárendelt jelentösége van a régión belïli kapcsolatoknak. Az ország gazdasági talpra állása után minden bizonnyal több esélye lesz a régión beliali közlekedés komplettírozásának, azaz a közhasználatú közlekedés regionális hálózatának kialakítása után a regionális léptékü, sajátos rendeltetésü és müszaki típusú infrastruktúra kiépitésére is sor kerülhet. A regionális közlekedés lényegét a terület méretgazdasága alapján két alapvetô, egymással szorosan összefüggö tényezö- a lépték és a funkció - határozza meg. Tehát a regionális közlekedés méretgazdasági alapon is középszint, mivel olyan nagyságrendi kiuszöbérték tartozik hozzá, amely bizonyos fajta és müszaki teljesitményü közlekedési infrastruktúra létesitésének és üzemeltetésének gazdaságossága szempontjából meghaladja a megyék által lehetôvé teti szintet.

A címben foglaltak szerint a tanulmány feladata kimutatni, hogy a közlekedés, illetve az egyes közlekedési alágazatok mely tulajdonságai relevánsak a regionális versenyképesség szempontjából. Miután e témát mélységében még nem kutatták, a válaszadáshoz az út a Terra inkognitán vezetett keresztül. Ezért első közelítésben a közlekedést is magában foglaló ágazat, az infrastruktúra szintjét vizsgáljuk meg.

Lengyel (2002) rendkívül széles spektrumú nemzetközi elméleti közgazdaságtani és térgazdaságtani irodalom kutatással igyekezett a térbeliség, a versenyképesség és az infrastruktúra lehetséges összefüggésrendszerét megismerni, a három fogalom, illetve jelenség határterủletét bejárva kapcsolódási pontokat találni. E törekvés csupán igen szerény eredménnyel járt, mert kiderủlt, hogy még a legmodernebb térelméletek, illetve infrastruktúra monográfiák sem közelítettek témájukhoz a Lengyel által felvetett, képviselt nézőpontból. 


\section{A versenyképesség, illetve a regionális versenyképesség vitatható tényezői}

Magyar és külföldi szerzők, sőt az EU irányvonalak is közgazdász „fejjel” lényegében a gazdasági teljesítményt tekintik a versenyképességet meghatározó tényezönek. Szerintük az egységes versenyképesség a globális versenyben elért olyan tartós gazdasági növekedés, amely egyaránt származik a magas munkatermelékenységböl és a magas foglalkoztatottságból, de olyan mutatóknak is van szerepük e szempontból, mint az adott gazdaság nyitottsága. Porter (2000) pedig erős egyszerüsítéssel a versenyképességet a termelékenységgel azonosítja.

Közgazdász körökben a makrogazdasági és a vállalati versenyképesség analógiájára a regionális versenyképesség fogalmát is közgazdaság-tudományi kategóriának tekintik. Lengyel (2002) szerint a regionális versenyképesség ,a területek közötti versenyben elért sikereket jeleníti meg." Bár a fö célnak ő is az adott területen élök jólétének tartós növelését tartja, de hangsúlyozza abban a gazdasági fejlődés meghatározó szerepét. Következésképpen az infrastruktúra elsősorban azon tulajdonságai révén válhat a regionális versenyképesség elemévé, amelyek hozzájárulnak a tartós gazdasági növekedéshez.

Végső soron a hagyományos felfogás szerint a regionális versenyképesség három (egymással kapcsolatban levő) közgazdasági kategória (jövedelmi szint, termelékenység, foglalkoztatottság) által meghatározott minőségi, illetve „eredményességi" tulajdonság, amely ugyan nem szinonimája a regionális gazdasági fejlödésnek (illetve fejlettségnek) - mivel annál összetettebb (más tényezökkel is kiegészülő), komplexebb ,fölérendelt” fogalom -, viszont a gazdasági fejlettség alapvetö követelménye a versenyképességnek, azt mintegy magába foglalja (1. táblázat).

Az egyes területek és települések közötti verseny igazi tétje és egyúttal mértéke véleményünk szerint az élet minösége, amely a gazdasági színvonalon, az anyagi javak birtoklásán kívül magában foglalja az olyan, ún. „puha” tényezőket is, mint a természeti és az épített környezet, a táj arculata, müvészeti értékek, kulturáltság, a népesség mentális állapota stb. Megítélésünk szerint az utóbbiaknak ugyancsak nem marginális a szerepe a „piramis” csúcsán megjelenő életminöség alakulásában.

Minden jel arra mutat, hogy a fejlett államokban a lakosság egyre kömyezetérzékenyebb lesz, értékrendjében a tágabb értelemben vett kulturális miliö, az esztétikus település-környezet és az emisszióktól nem túlterhelt, elviselhető, illetve adottságainál fogva szép természeti környezet minősége mind elökelőbb - esetenként az anyagi jóléttel egyenértékü - helyet foglal el. Miután a dezindusztrializációval a legtöbb fejlett és közepesen fejlett régióban/országban a közúti közlekedés vált az elsö számú környezetszennyezővé, a közlekedés minőségének (modal split, fajlagos és abszolút emisszió, közlekedési mód, mobilitás stb.) meghatározó szerepe lehet az ökológiai állapotban, végső soron a regionális versenyképességben is. (Olyan alapon, hogy a nagy anyagi értéket termelő, de egészségtelen, környezetileg penetrált régiók nem attraktívak, egy idő után nemcsak a lakó, hanem a termelő funkciók számára sem.) 
Gondolatok a közlekedés szerepéröl a régiók/városok versenyképességének alakulásában. Tér és Társadalom, 16. 2002. 1. 135-159. p.

TÉT XVI. évf. 2002

Versenyképesség

137

\section{TÁBLÁZAT}

A regionális gazdasági fejlödés és a regionális versenyképesség viszonya; avagy szinonimája-e egymásnak a két tulajdonság?

(Relation between Regional Economic Development and Regional Competitiveness; are these features synonym?)

\begin{tabular}{c}
$\begin{array}{c}\text { A regionális fejlödés, illetve fejlettség } \\
\text { (több változóra bontható komplex folyam }\end{array}$ \\
\hline Összetevöi: \\
- a gazdasági szerkezet \\
- az egy lakosra jutó GDP/GNP \\
- az innovációs szint/csúcstechnologia \\
- aránya \\
- az átlagos személalkoztatottság/munkedelem \\
- a munkaeró kvalifikációja \\
- a demónálat \\
- a kórnyezeti/ókológiai viszonyok \\
- az infrastrukturális ellátottság
\end{tabular}

A regionális fejlesztés célja

- a területi fejlettségbeli különbségek mérséklése

- a hatékonyság javítása

- a környezet állapotának javítása

Forrás: Saját szerkesztés.
Regionális versenyképesség

a) Gazdasági (, kemény”) kritériumok

- Hatékonyság

alakulása

$$
\begin{array}{cl}
\underset{\text { időben }}{\text { iz }} & - \text { Foglalkoztatottság } \\
& - \text { A gazdaság nyitottsága }
\end{array}
$$

dinami-

kája

b) Környezeti, kulturális/ életminőségi (,puha”) kritériumok

- szerepük a jövőben nơvekszik, ezért mind nagyobb súllyal figyelembe veendô

\section{Az ágazati megközelités elhanyagolása, illetve integrálásának nehézségei a regionális versenyképesség kutatásokban}

Számunkra, akik korunk leggyorsabban felértékelödő ágazatával, a kőzlekedéssel (és távközléssel) foglalkozunk, komoly hiányosságnak tủnik, hogy a regionális versenyképesség Lengyel-Deák (2001) által is elfogadott tematikus tartalmú szerkezetébe (,piramismodelljébe”) nehezen illeszthetők az ágazatok, illetve, hogy a jelenségnek formálisan nincs ágazati dimenziója. A többi ágazat (mezőgazdaság, ipar, kereskedelem, idegenforgalom stb.) sincs jelen a régiók (térségek, városok) versenyképességének piramismodelljében.

A közlekedés sem ágazatkẻnt, hanem egyrészt az infrastruktúra részeként jelenik meg a szakirodalmi fejtegetésekben, másrészt a regionális elérhetóség mint az alap- 
kategóriákat meghatározó egyik alaptényező van jelen. Pedig a regionális versenyképességnek (tehát a régiók azon tulajdonságának, hogy a versengésben való helytállásban megfelelö képességet tanúsítanak, illetve sikert mutatnak fel) számos összetevôje van, amelyek konkrétan az egyes ágazatokhoz kötỏdve manifesztálódnak.

Amikor a vállalatok közötti versenyben a közlekedés (és azon belül az egyes alágazatok) szerepét kell tisztázni, hipotézisként kiindulhatunk az infrastruktúrán belül az általános és speciális tényezök Porter által megkülönböztetett csoportjainak a versenyképesség szempontjából nagyon különbözỏ hatásaiból, viselkedéséből.

- Az általános tényezők/infrastruktúra elemek körébe olyan hagyományos infrastruktúrák tartoznak, amelyek az iparágak széles körében csökkenthetik a versenyhátrányt, illetve legfeljebb az alacsonyrendủ előnyöket támogatják. Porter ide sorolja az autópálya rendszert, a távközlést és a felsőfokú végzettségủ motivált munkaerőt,

- igazi magasrendü versenyelönyöket azonban csak az ún. speciális tényezök hoznak létre. Ezek közé tartoznak a speciális szakképzést (pl. müszaki $\mathrm{PhD}$ képzést) nyújtó intézmények, egyedi infrastrukturális létesítmények (logisztikai központ), magas presztízsü, különleges ismereteket hordozó $\mathrm{K}+\mathrm{F}$,tudásgyárak" stb.

Miután csak az innovatív „csúcsinfrastruktúra” képes magasrendü versenyelőnyöket teremteni, Lengyel (2002) szerint témánk szempontjából nincs értelme annak a kérdésnek, hogy egy régióban általában mennyire fejlett az infrastruktúra, illetve, hogy egy-egy ágának elterjedtsége, teljesítménye az országos átlag mekkora hányadát éri el. A lényeges kérdést abban látja, hogy a térség meghatározó iparágainak tartós, magasrendü versenyelőnyéhez elégségesek-e a fejlett és speciális infrastruktúra elemei. Az utóbbi kitétellel egyetértve arra kell tehát törekedni, hogy a valamennyi infrastruktúra alágazatra kiterjedö általános vizsgálat helyett egy-egy terület, település gazdasági szerkezetének figyelembevételével a leghatékonyabbnak, legfontosabbnak talált speciális infrastruktúrákra összpontositson a vizsgálat. Még ennél is fontosabb azonban a speciális infrastruktúrákkal szembeni követelményeknek legalább az országok általános fejlettségi szintje szerinti differenciálása:

- a Porter-féle követelmények igazak lehetnek a fejlett országokban kialakult gazdasági környezetre, viszont

- a fejletlen országokban/régiókban még az olyan általános tényezők is jelentőséget nyernek, mint az autópályák.

Az imponáló szélességủ és mélységủ szakirodalom tanulmányozás után Lengyel $(2002,29)$ kénytelen a tanulságokat summázva megállapítani, hogy ,arra a kérdésre, miszerint milyen kapcsolat van az infrastruktúra és a versenyképesség között, nem lehet megalapozott választ adni, mivel maga a kérdésfeltevés sem jó. A helyes kérdés csak az infrastruktúra egy-egy konkrét részterületének (pl. közlekedés, kommunikáció, oktatás stb.) és a régió domináns iparágai (klaszterei) kapcsolatára vonatkoznak, $\mathrm{pl}$.... a versenyelönyökhöz hogyan járulnak hozzá.". 
Az alábbiak tükrében csupán féligazságokat tartalmaz Lengyelnek és Deáknak (2001, 98) az az állítása, hogy „A kevésbé szállításigényes tevékenységeknél, föleg a kommunikációs kapcsolatokra épülő üzletágakban nem a fizikai, hanem az informatikai elérhetőség a döntő, ezért pl. az autópályák hiánya nem jelent komoly versenyhátrányt, mivel a nehézkes földrajzi elérhetőség, a földrajzi tér helyett a virtuális tér válik fontossá." Nézetünk szerint az autópályák legnagyobb előnye a sebesség, ami elsősorban a személyközlekedésben követelmény, ezért az autópályák nem annyira az áruszállítás, mint inkább a személyautóval való távolsági közlekedés szempontjából kiemelkedő jelentőségúek. Ennél lényegesebb kérdés azonban a közlekedés távközléssel való helyettesíthetőségének kérdése. Kétségtelen, hogy az 1980-as évek végén az euforikus légkörben technokraták által készített prognózisok szerint az informatikai/telematikai eszközök széles körü használata a helyettesités által forgalomcsökkenéshez, ezzel a közlekedés jelentőségének gyengüléséhez ve$z e t . E$ váltás azonban még a legfejlettebb országokban sem következett be, mivel a face to face kommunikáció nélkülözhetetlennek bizonyult az üzleti életben is, de az áruszállítás kocsikilométer-teljesítményei sem csökkentek (csak a tonna és tonnakilométer volumen csökkent a nehézipar és építőipar összeomlása következtében), ugyanis a távvásárlás elterjedésével és a kisvállalkozók, valamint a szolgáltatószerviztevékenységek nagyarányúvá válásával a kistételes szállítás ma jóval elterjedtebb, ezért az úthálózat terheltsége nem javult, sőt romlott. Ezen a helyzeten pedig gyorsforgalmi utak építésével lehet javítani. Fejlett, versenyképes országokban és régiókban az autópályák szükségtelensége inkább csak az alacsony népsürüség/településsürüség esetén fogalmazható meg - amennyiben nincs nagy volumenủ tranzitforgalom.

A versenyképes régiók négy jellemzője közül az egyik az elönyösebb „regionális elérhetöség." (A megfelelő gazdasági szerkezet, a képzett munkaerỏ és az innovációs tevékenységek kiterjedtsége mellett.) Az EU-s koncepció szerint fontosságban csupán a 8. helyen álló elérhetőség/megközelíthetőség Lengyel-Deák (2001) szerint az utazási időigény és a piac méretének kombinációjából adódik. E tényezö függvényében alakul a régióban előállított termékek és szolgáltatások megrendelőkhöz való eljutásának ideje, de áttételesen a közlekedési infrastruktúra minőségére is utal. A megközelíthetőség ugyan alapvető fontosságú a versenyképességhez, de hatását tulajdonképpen más tényezőkön, főként a gazdasági szerkezeten keresztül fejti ki.

Úgy gondoljuk, hogy a vizsgálatok során meg kell haladni a sajátosan értelmezett "regionális elérhetöséget”. Ugyanis e fogalom interpretációiban csupán egy régió kiulső közlekedési kapcsolatairól, a „kívülről” (más régiókból, országokból) való elérhetőségéröl van szó, viszont a régión belüli (intraregionális) elérhetöségi viszonyok minősége nem tartozik a kritériumok közé. Elismerve, hogy a globalizálódó világunkban, a gazdaság nyitottságának fokozódása idején a külvilággal való összeköttetéseknek, a külső piacok elérhetőségének (és ellenkező irányban a régió szomszédos és távolabbi térségekböl való elérhetőségének) kiemelkedő jelentősége van, nem szabad arról sem megfeledkezni, hogy a gazdasági klaszterek müködésének hatékonyságától a kulturális élet hálózatosodásáig és végső fokon az életminőségig 
a régió teljes gazdasági/társadalmi életére nagy hatással van a régióközpont és az alközpontok elérhetôsége az inkább „illetékességi területnek” definiálható vonzásterületükröl, ahogyan az alközpontok közötti összeköttetések minösége sem közömbös.

Lengyel - egyébként rendkívül magas színvonalú - fejtegetéseinek néhány közlekedési vonatkozású megállapításából a következöt emeljük ki a polémia igényével: „A közlekedés és távközlés fejlödése, az áru-, személy-és információszállitás olcsóbbá, gyorsabbá és nagy tömegeket megmozgatni képessé válásával a gazdaságitársadalmi tevékenységek egyre nagyobb hányada vált térben mobillá. A mobil szektorbeli gazdasági tevékenységek fuggetlenítődnek a tértöl, elvesztik adott térségekhez/telepuilésekhez való konkrét kötődésilket és gyakorlatilag a világ bármely részén folytathatók." - Vitathatatlan, hogy kirajzolódik némely vonatkozásban és szektorban ez a tendencia, de egyelöre még nem így múködik a világgazdaság. Egyáltalán nem lehetetlen, hogy a jövően a fajlagos szállítási/közlekedési költségek növekednek, ahogyan az EU közlekedéspolitikájának érvényesülésével az externáliákat internalizálják (ökoadó, útdijjak, kerozinadó stb.).

Az egyes régiók közlekedésének versenyképességét (Lengyel Imrének a regionális versenyképességéről szóló meghatározásához igazodva) elvileg vagy a mikroszintből kiindulva (tehát az ottani vállalatok versenyelőnyeinek összegzésével), vagy a makroszintü versenyképesség felfogásokat alkalmazva, azaz dezaggregációval célszerü meghatározni.

Azonban a mai feladatunk nem a régiók közlekedése versenyképességének vizsgálata, hanem annak a - Magyarországon még egyáltalán nem, de külföldön is alig kutatott - kérdésnek a megválaszolása, hogy a közlekedésnek mi és milyen lehet a szerepe a régiók, városok versenyképességében? (A régió fogalmat természetesen rugalmasan kell értelmeznünk, mivel Magyarországon az ,igazi” funkcionális régiókat még jó ideig kénytelenek leszünk nélkülözni.)

$\mathrm{Az}$ ismétlést elkerülendö e helyen nem foglalkozunk a regionális közlekedési rendszerek mibenlétével (Erdösi 2000a).

\section{Valójában hol a közlekedés helye a regionális versenyképességben? - Elözetes felvetések a kutatás irányáról és lehetöségeiröl}

Amennyiben elfogadjuk a Lengyel (2002) által is képviselt felfogást, hogy „regionális szinten általános, komplex versenyképesség fogalom megadására kell törekednünk, nem pedig egy-egy önmagában fontos résztényező (például költség, export, munkaerö, müszaki stb.) kiemelésére" (Lengyel 2000, 970-971), úgy ezen az alapon az egyes ágazatok is csak résztényezönek minősülnek, tehát a közlekedés kiragadásának (mint ahogyan az ipar, mezőgazdaság, szolgáltatások kiragadásának) sincs igazán értelme. Nyilvánvaló ugyanis, hogy a mégolyan kiváló közlekedés sem lehet önmagában garancia egy régió („össz”) versenyképességéhez, ha más kemény feltételek hiányoznak. (Pl. ha egyébként versenyképtelen ipari és mezőgazdasági 
termékeket állít elő, illetve ha alacsony szintủ, elégtelen az egészségügye, oktatásügye, ha rossz a kommunális vagy éppen a termelési infrastrukturális ellátottsága.)

Az alapvető kérdés tehát az, hogy szoros-e a korreláció a közlekedés fejlettsége és a régió versenyképessége között? Az előbbi pontban kifejtettek ellenére úgy gondolom, hogy sokáig nem állhat fenn diszkrepancia egyfelöl a régió egyes ágazatainak (par excellance a közlekedésnek/távközlésnek), másfelöl a régió összteljesítményének a versenyképessége között. Mennél inkább a globális szintet közelítik egy régió külső kapcsolatai, és mennél nagyobb a régión belüli (koncentrálódással, polarizálódással járó) területi munkamegosztás, annál nagyobb jelentőséget kap az árukat, személyeket és információkat szállító tevékenység.

A közlekedés és távközlés szerepének a regionális/települési versenyképesség alakulásában való kimutatása történhet

a) Elméleti megközelítésekkel, amelyek

- a közlekedésnek a régiókbeli termelékenység/hatékonyság alakulásában elfoglalt helyének kimutatására irányulnak. Úgy látjuk azonban, hogy az eddig ismert elméleti megközelítések meglehetősen megbízhatatlanok, eredményeikben végletesek.

- A régiók gazdasági fejlettsége (a termelékenységet is tükrözö GDP) és a közlekedés fejlettségének komplex mutatói közötti korrelációszámítások eredményeinek felhasználásával.

b) A különböző országokból és régiókból származó gyakorlati tapasztalatok felhasználásával, amelyek alapján megfogalmazható, hogy milyen hatással voltak a nagyszabású közlekedési infrastruktúra (vasút, autópálya, óriáshíd) építések a régiók - versenyképességüket is befolyásoló -- fejlettségére. Milyen egyéb tényezök együttállására van szükség ahhoz, hogy a közlekedés ténylegesen és kimutathatóan hozzá tudjon járulni a versenyképességhez, hol és miért nem tudott lendíteni a gazdaságon a mégolyan modern közlekedés sem.

A közlekedésnek (miután a keresőknek mindössze a 4-8\%-át reprezentálja) nincs különösebb hatása a foglalkoztatottsági ráta alakulására, viszont az átlagosnál valamivel magasabb képzettséggel a régiók munkaerö-állományának kvalifikáltságára már igen. Ennek ismeretében nem látjuk értelmét a foglalkoztatási hatások mélységi vizsgálatának.

c) Külföldi szakirodalom feldolgozásával (erre nem került sor, mert érdemi anyagot nem találtunk).

A közlekedés viszonylagos versenyképességének kimutatásához a Világgazdasági Kutatóintézetben lajstromozott és gyüjtött adatokon kívül javasoljuk a közlekedési hálózatok gráf vizsgálatát is elvégezni. Erre azért lenne szükség, mert a fajlagos hálózatsürüség önmagában nem ad elég muníciót a hálózat értékeléséhez. A közelítően azonos sürüségü és minőségü hálózatok forgalmi hatékonyságát nagyban befolyásolja alakzatuk, a csomópontok és az összeköttetések, valamint a szárnyvonalak/bekötöutak aránya stb. Tudatában kell lennünk annak, hogy a kỏzlekedési hálózatok történelmileg kialakult, sokféle területi érdek üt- 
közése és kompromisszuma eredményeként kialakult jellemzői (a múlt „bünei” és „erényei”) is összetevői lehetnek a versenyképességnek, miután a hálózatok geometriai szerkezete befolyásolja a használati értéküket, a terület feltárására való alkalmasságukat is.

\section{A közlekedés (mint ágazat) szerepe a régiók versenyképességében}

A közlekedésnek a regionális fejlödésre való hatásáról alkotott elképzelések elöször a vasútkorszakban születtek meg, és azóta valamennyi új közlekedési eszköz megjelenése eufórikus véleményeket váltott ki az elvakult ügyszeretet és a féktelen mobilitási igények feltételezése okán. Az egykor elvárt fejlödési impulzusoknak azonban csak egy része vált valósággá, meglehetősen rapszodikus megoszlásban. Annak ellenére, hogy az utóbbi évtizedekben - mindenekelött a szabadidős mobilitás és a globalizálódással a közlekedési térstruktúrák átrajzolódása folytán - új keletü folyamatok bontakoztak ki, a politikai döntéshozók többsége, de gyakran a közlekedési szakemberek is anakronisztikus módon a közlekedéstöl még mindig a régi idökre jellemzö hatásmechanizmust várnának el, holott a jelen már egészen másról szól, és tulajdonképpen már ma a jövöben várható helyzetnek megfelelöen kellene tervezni.

Elfogadva a versenyképesség alapvető gazdasági kritériumait (az átlagot meghaladó jövedelmi szintet, a termelékenységet, a foglalkoztatottságot), meg kellene mondani, hogy e kedvezö tulajdonságok megjelenéséhez hogyan képes hozzájárulni a közlekedés.

Úgy gondoljuk, hogy a gazdasági folyamatokban az elöbbi feltételek mindig együttesen jelennek meg, legfeljebb csak kisebb pozitív és negatív arányeltolódások mutatkoznak közöttük, ezért nem érdemes egyenként, külön-külön vizsgálni az egyes elemekben tettenérhetỏ hatásokat. Az olyan eseteket ugyanis, amikor az egyik elem (pl. a termelékenység) a másik (pl. a foglalkoztatottság) rovására erösödik, és ezáltal egyensúlyzavarok állnak elö, csak átmenetinek tekinthetjük, mert hosszú távon a három elem egymáshoz való viszonya megfelelỏ stabilitást kell, hogy mutasson.

A közlekedés hatásait több metszetben vizsgáljuk, úm.

- a közlekedési kínálat oldaláról

$\Rightarrow$ a közlekedési infrastruktúra, elsősorban a pálya/úthálózat létesítésének, építésének hatásait a régiókra,

$\Rightarrow$ a közlekedési infrastruktúra igénybevételének, használatának, illetve a létrejött közlekedési szolgáltatásoknak hatásait a régiókra,

- a közlekedés keresleti oldalát e tanulmányban nem vizsgáljuk, mivel a termeléssel és fogyasztással kapcsolatos közlekedési/szállítási szükségletek csak erősen áttételesen játszanak be a versenyképességet megteremtő folyamatokba. 
Általános - még a legfejlettebb országokra, régiókra is érvényes - tapasztalat, hogy a legtöbb esetben a közlekedési kereslet növekedése készteti a pálya és jármü tulajdonosokat a további beruházásokra, a szolgáltatókat a szolgáltatások bővítésére, azaz együttesen a közlekedési kínálat növelésére. A tarthatatlanná váló szük kapacitások kikényszerítik a fejlesztést; amely így alapvetően követỏ jellegüvé válik. Meglehetösen kevés példát találunk nemcsak Kelet-, hanem NyugatEurópában is arra, hogy a közlekedési infrastruktúra és a szolgáltató vállalatok tulajdonosa a kényelem, a pontosság stb. érdekében távlatos gondolkodással nemcsak kapacitásban nagyobb, hanem minöségében is lényegesen jobb kínálatával hajlandó elébe vágni a keresletnek, azaz átmenetileg „kínálati piacot” hoz létre a „túlkínálattal”. (E tekintetben a MÁV keretein belüli jelenlegi kínálat/kereslet viszony sem kivétel, a mellékvonal-hálózati gyenge kapacitáskihasználtság tulajdonképpen virtuális, mert jobbára a szolgáltatás minőségében mutatkozó évszázados elmaradásnak, azaz a minöségi oldal teljes elhanyagolásának a következménye.)

\section{A közlekedési kínálat növelésének hatásai}

\section{Pálya-/út- és csomópont építések', valamint a jármübeszerzések regionális következményei}

Vasutak, állomások, autópályák, hajózó-csatornák, tengeri és folyami kikötők építéséhez, felszereléséhez, berendezéséhez szükséges anyagok (sín, talpfa, építöanyagok, épületgépészeti berendezések, távközlési és más müszeres felszerelések, daruk, rakodó-berendezések stb.), továbbá jármúvek (mozdonyok, vasúti kocsik, közúti jármủvek, hajók) és biztosító berendezések iránti keresiet az ezeket termelö iparágak növekedésének gyorsulásához vezet. E hátrakapcsolódási hatás (backward linkages, illetve a feedback hatás) erőssége azzal mérhető, hogy ezen iparágak (kohászat, hengerdék, gépipari, távközlési felszerelést eloállító, mély- és magasépítő szektor stb.) a teljes kibocsátásuk hány \%-át szállították/-ják a felsorolt közlekedési alágazatoknak (Erdősi 2000c).

A szakosodással kapcsolatos (alágazati és területi) szélesebb körủ munkamegosztás folytán ritka az olyan eset, hogy egy adott régió a közlekedési beruházási inputjának túlnyomó részét saját outputjából képes fedezni. Következésképpen a megrendelések többsége általában más régiókbeli ipari tevékenységek bevételét gyarapítja. Söt, mennél elmaradottabb a régió országa, annál nagyobb a valószínüsége annak, hogy fejlettebb országokbeli felszerelésekkel épül meg a pálya, amelyen külföldről származó jármủveket közlekedtetnek. (Ez jellemezte a 19. századi hazai vasútépítéseket, de az utóbbi évtizedekbeli autópálya építéseket is a Kárpátmedencében, illetve Kelet-Európában, amikor a díjszedö kapuktól az optikai kábelekig sokféle müszaki anyagot külföldön kellett beszerezni.)

Ez a hátrakapcsoló hatás azonban csak rövidebb-hosszabb ideig vagy időben nagyon rapszodikusan javítja a beruházásokat kiszolgálók gazdasági kondícióit a 
megrendelések, a bevételek növelésével. Van azonban olyan hozadéka is e folyamatnak, hogy az átmenetileg megugrott kereslethez alkalmazkodva nagyobb méretgazdaság, kapacitás áll elő, ehhez új, (a Parker féle speciális infrastruktúra elemeket erösítö) innovatív, termelékenyebb technológiákat vezetnek be, amelyek elsörenden a régió összgazdaságának hatékonyságát javítják.

A nagy közlekedési infrastruktúrák (vasutak, autópályák) tervezésének legtöbb mozzanata többnyire nem a vidéki régiókat, hanem a fövárost, illetve a ,magrégiót”, valamint a legnagyobb néhány gazdasági kỏzpontot gyarapítja, mert hogy az elötanulmányokat, megvalósíthatósági tanulmányokat, elözetes környezeti hatásvizsgálatokat éppen úgy nem „vidékiek” készítik, ahogyan az átfogó és részletes műszaki terveket sem.

A nagy közlekedésépítési munkák kivitelezését (generálvállalkozóként), a legfontosabb és legnagyobb volumenü építkezési feladatok (földmunkák, felépítmény, betonburkolat) elvégzőjeként is általában az ilyen léptékủ munkákhoz megfelelö gépparkkal, felszereléssel, erre speciálisan képzett munkaerővel rendelkező, a politikai döntéshozókhoz földrajzilag is közeli, országos kompetenciájú nagyvállalatok látják el, amelyek persze kisebb volumenű, kevésbé jól fizető részmunkákat kiadnak vidéki kis-, esetleg középvállalkozóknak. Abban a régióban, ahol az építő munkák folynak, az építkezés idején inkább csak a foglalkoztatottakat kiszolgáló vállalkozók (szállásadók, élelmiszer- és italboltok, vendéglátók stb.) forgalmának/ bevételének javulásában (helyenként akár hónapokig tartó megtöbbszöröződésén) nyilvánul meg az akcellerátor hatás.

A hátrakapcsoló hatás további következménye a tökekoncentráció fokozódása. Vasutak, autópályák, nemzetközi repülőterek, hajózó-csatornák, kikötők építéséhez különleges nagyságrendü tőkére van szükség, nem ritkán beruházási célbankok létesülnek, amelyek a finanszírozás befejezése után kereskedelmi bankokká, lakossági takarékpénztárakká alakulnak át - mint ahogyan az a magyarországi vasútépítésekkel kapcsolatban is történt. (Arról sem szabad megfeledkezni, hogy a beruházásokhoz szükséges tỏkék előteremtése érdekében már mozgósították a lakossági megtakarítások nagy részét.) Ezek jelentősen hozzájárultak az urbanizációhoz, illetve a gazdaság más szektorai tỏkeszükségletének kielégítéséhez. Mind a 19-20. századi vasúti beruházások, mind az 1930-as évektől kezdődö autópálya építésekkel kapcsolatos többirányú tőkemozgás, foglalkoztatástöbblet kedvezően befolyásolta azoknak a regionális gazdaságoknak a stabilitását, amelyeket a termelés, a gazdasági tevékenységek ciklikus ingadozásai sújtottak/-nak. E kontraciklikus hatás még az 1990-es évek első felében is érzékelhető volt az MI autópálya befejező szakaszának megépítésével kapcsolatban, és ez a közvetlenül érdekelt Észak-Dunántúlon kívül a Dél-dunántúli régiót is kedvezően érintette (a komlói kőanyag folyamatos szállításával). 
Gondolatok a közlekedés szerepéröl a régiók/városok versenyképességének alakulásában. Tér és Társadalom, 16. 2002. 1. 135-159. p.

TÉT XVI. évf. 2002 - 1

Versenyképesség

145

\section{A közlekedési infrastruktúra használatának, illetve a létrejött közlekedési szolgáltatásoknak a hatása a régiókra}

Megépülésük, használatba helyezésük után a vasutak, autópályák, vízi utak, nagy kikötők, repülöterek múködésükkel, a rajtuk (illetve segítségükkel) végzett közlekedési szolgáltatásokkal lehetővé tették a potenciális utasok közlekedését, a tömeges és a minőségi áruszállítást, továbbá a különféle célokra differenciált közlekedési eszközökkel a korábbi helyzethez képest lényegesen csökkentették csaknem valamennyi áru szállítási költségét. Ennek az elörekapcsolódó hatásnak (forward linkages) kedvezö hatása volt a teriuleti specializációra, ösztönzö a kereskedelemre. Ugyanakkor a nagyteljesítményü infrastruktúrák (mintegy pozitív külső hatásként) a tölük való távolság függvényében erösen differenciálták a területi fejlödést a ráfordítások és szállítási költségek által is alakított árkülönbségek révén:

- A vasúti fövonalak (pályaudvarok), autópályák (ráhajtóágak) és nagy kikötők, repülöterek mellett sürüsödtek a termelöüzemek és szolgáltató telephelyek, ide telepedett át a kvalifikált és fiatalabb munkaeró, a lakosság legkreatívabb, vállalkozó szellemú része, mint ahogy itt vált a legkedvezőbbé az információ csere is a társadalmi méretủ kommunikáció révén, a legjobb feltételek teremtődtek a nagytávolsági kereskedelemhez és termelési kooperációhoz, jó lehetőségek adódtak a távolibb foglalkoztató kózpontokba, munkahely tömörülésekbe való ingázásra, felértékelődtek a telephelyek. A magisztrális vonalak mentén kialakultak a fejlödési tengelyek, innovációhordozó folyosók és idővel összefüggő fejlődő térségek alakultak ki. Ahol csak szegmentált és nem összefüggő volt a magisztrálék menti területi fejlödés, annak elég sok esetben éppen az volt az egyik fó oka, hogy a magasabb jövedelmek elérését lehetóvé tevő ingázás tömegessé válásával, majd a vidéki lakosság csomópontokba való beköltözésével a telephelyek kénytelenek voltak koncentrátumokat alkotni.

- A vasúti mellékvonalak, másodrendü utak és térségi jelentőségü alsóbbrendü utak, kiskapacitású hajózócsatornák, valamint kisebb repülöterek mellett, ezek vonzássávjában a népességszám stagnálása, a népességstruktúra konzerválódása, az állomások melletti területeken kitermelőipari telephelyek kialakulása, a lakóhelyérték konzerválódása vagy gyenge növekedése volt a jellemző.

- Azok a mögöttes (,periferikus”) térségek viszont, amelyekben a közlekedők csupán a meglehetősen rossz minóségủ (nem egyszer kiépítetlen) alsóbbrendú utakra voltak kénytelenek hagyatkozni (a szélsőséget itt a bekötő utak képviselték), a népességelvándorlás, illetve elöregedés, az alacsonyan maradt kvalifikációs szint, a kedvezỏtlen demográfiai struktúra, a mezỏgazdasági termelés szerkezetromlása, hatékonyságának gyengülése, a kisipar visszafejlődése következtében kiüresedó, visszafejlödő térségek jelentek meg az elmaradottság valamennyi szimptómáját felmutatva (Erdősi 1991). 


\section{A közlekedés alágazati szerkezetének (modal split) hatása}

A régiók versenyképességének alakulásában a közlekedés alágazati szerkezete is szerepet játszik.

Abból indulhatunk ki, hogy a közlekedés abban az esetben képes a legjobban hozzájárulni a versenyképességhez, ha kínálatának szerkezetében a legnagyobb mértékben képes igazodni az adott régió sajátos természeti-gazdasági-társadalmi adottságaihoz, struktúrájához, az abból adódó konkrét közlekedési/szállítási igények mennyiségéhez, tételeihez és területi megoszlásához, mert ilyen módon képes a leghatékonyabb lenni.

A földi közlekedési alágazatok teljesítménye közötti arányok tekintetében általában csupán annyi állapítható meg, hogy

- a legkorszerübb szerkezetủ szolgáltatói társadalom és gazdaság igényeinek a gazdasági hatékonyság szempontjából olyan közlekedés felel meg,

$\Rightarrow$ amelyben a személyközlekedés túlsúlyban van a teheráru szállítással szemben,

$\Rightarrow \quad$ amelyben abszolút fölénye van a kis tételes áruszállító (föként fogyasztási cikkeket fuvarozó) és személyautós közúti közlekedésnek,

$\Rightarrow$ amelyben a rugalmatlan vízi és vasúti áruszállítás csak alárendelt jelentöségü,

- az ökológiai fenntarthatóság szempontjából viszont a legkevésbé környezetterhelö alágazatok (vízi és vasúti közlekedés) magas aránya a kedvező.

Az elöbbi két teljesen különböző szempont közötti kompromisszum közlekedéspolitikailag napjainkban már elfogadható, sőt akár kedvezőnek is számító megoldásnak értékelhető.

A régió adottságaihoz, elvárásaihoz való alkalmazkodás elve konkrétan azt jelenti, hogy vasúti célforgalmi jellegü áruszállitásra (mellékvonalakon, belföldi végpontú fövonalon) akkor van szükség, ha a régióban nagy szállitásigényü tevékenység folyik. Ezek közé tartozik hazai viszonylatban a még múködő nagyüzemi szén-, kőés kavicsbányászat, cement- és mészhidrátipar, de az intenzív, nagy hozamú és összpontosított mezőgazdasági (pl. cukorrépa, burgonya, kukorica, gabona) termelés is mint kibocsátó, különösen abban az esetben, ha az ország távolabbi térségeiben levő feldolgozó helyekre (pl. a megritkult cukorgyár hálózat valamelyik telephelyére vagy exportra) kell szállítani irányvonatokkal. Kiterjedt, rendszeres kitermelést folytató nagy fahozamú erdőségek is indokolhatják más, nagy volumenủ kibocsátókkal együtt vasúti mellékvonalak fenntartását. Ahol viszont nincsenek, vagy csak a térben erősen szétszórtan, kisebb areálokra szorítkozva találhatók nagy terméshozamú, intenzív termöhelyek, a termények összegyüjtéséhez, belföldi fogyasztókhoz vagy feldolgozó-központokba szállitásához a közúti jármü az adekvát közlekedési eszköz. Ahol a bányák és a felhasználó terület között vízi út létezik, ott számításba jöhet a folyami szállítás is. Erre lehetőség Magyarországon kevés helyen van, de szervezési nehézségek, a kikötők siralmas állapota és a sajátos ágazati árak miatt még az elvileg számításba jövő viszonylatok sincsenek kihasználva. 
Gondolatok a közlekedés szerepéröl a régiók/városok versenyképességének alakulásában. Tér és Társadalom, 16. 2002. 1. 135-159. p.

TÉT XVI. évf. 2002 - 1

Versenyképesség

\section{Az egyes közlekedési alágazatok/közlekedési eszközök \\ (közvetlen és közvetett) hatásainak értékelése a regionális versenyképesség szempontjából}

Az alábbiakban három fỏ szempont, a gazdaság hatékonysága, a foglalkoztatás és a környezeti hatások szempontjából elemezzük az egyes közlekedési alágazatokat. Az 1. táblázatba foglait minősítések természetesen nem egzakt számításokkal, hanem meglehetősen szubjektív becslésekkel kialakított kategóriák, amelyekkel csupán az egymáshoz való viszonyukat szerettük volna érzékeltetni.

\section{A hagyományos közlekedési eszközök hatásai}

A történelmileg egyik legrégebbi tömeges szállítási eszköz, a belvízi közlekedés természeti feltételei nem minden régióban adottak, így földrészünkön eleve csak a régióknak mintegy egyötödében van jelen. Miután a fajlagosan kis értékủ tömeges anyagok szállításának adekvát eszköze, és ilyen anyagok iránt egyre kevesebb az igény (és ha van ilyen szállítmány, azt újabban a gyorsabb és kiterjedtebb vasúti és közúti hálózaton szállítják), jelentösége az adott régiók versenyképességében a gazdasági hatékonyság és a foglalkoztatás tekintetében minimális, amit a kedvezö környezeti tulajdonsága sem tud ellensúlyozni (2. táblázat).

\section{TÁBLÁZAT}

Az egyes közlekedési eszközök/alágazatok hatása

a régiók versenyképességének egyes elemeire

(The Effects of the Different Transportation Sectors on the Individual Elements of Regional Competitiveness)

\begin{tabular}{lccc}
\hline Közlekedési eszköz/alágazat & $\begin{array}{c}\text { Gazdasági haté- } \\
\text { konyságra }\end{array}$ & $\begin{array}{c}\text { Foglalkoz- } \\
\text { tatottságra }\end{array}$ & Környezetre \\
\hline Nagysebességú vasutak & +++ & + & +++ \\
Hagyományos vasutak & + & + & ++ \\
Közúti közlekedés & +++ & + & +- \\
Belvízi hajózás & + & + & +++ \\
Tengerhajózás ${ }^{a)}$ & +++ & ++ & + \\
Csóvezetékes szállítás & +++ & + & +++ \\
Légi közlekedés & +++ & + & - \\
Távközlés/telematika & +++ & ++ & +++ \\
\hline
\end{tabular}

Fokozatok: + gyenge, ++ jó, +++ igen jó

- kedvezőtlen, -- rossz, --- igen rossz

a) a kikötői tevékenységekkel együtt

Forrás: Saját szerkesztés.

A tengeri közlekedésben az utóbbi fél évszázadban a hangsúly erösen eltolódott az áruszállítás felé, miközben a személyszállítási teljesítmény a linerhajózás terén Európában teljesen jelentéktelenné vált, és ma a személyszállítás (többnyire kombinált módon) a komphajózásba és az üdülöhajózásba vonult vissza. A régiók ver- 
senyképessége szempontjából ma a megfelelö gazdasági szerkezetủ és külkereskedelmi orientációjú „,hátországgal”, valamint müszaki felszereltséggel és legfőképpen modern logisztikai rendszerekkel, sokirányú összeköttetéssel rendelkező kikötök igazán relevánsak. Teljes egyértelmüséggel állítható, hogy ma Nyugat-Európa versenyképességben élenjáró régiói között igen sok olyan kikötövárossal rendelkezik (többnyire igazgatási központként is), amely nem csupán ,harbour”, hanem igazi „port”, azaz a jelentős berakó és kirakó (fizikai) forgalmon és kikötői feldolgozó iparokon kívül a tengerhajózási hagyományokra alapozott igen széles körü kiegészítő infrastruktúrák, intézmények, speciális üzletek, kulturális és oktatási intézmények révén rendkívül diverzifikált, egymással interdependens és komplexumot alkotó tevékenységek szintere, az utóbbi idökben a globális kommunikáció központjának szerepét is betöltve (Erdösi 1992).

A jobbára monostrukturális gazdasági alapú (árurakodásra, tisztán közlekedésre és a hagyományos kikötőiparok - pl. rizshántoló, kávépörkölö, malom vagy éppen olajfinomító, kohászati ipar - müködtetésére korlátozódó), az „ipari társadalom” fokozatán megrekedt kikötővárosok túlnyomó többsége ma strukturális válsággal küszködik, súlyos szociális problémák húzzák vissza. Hatásukra régiójuk is általában reménytelen helyzetbe került a versenyképesség szempontjából.

Ezzel szemben a kiváló és megbízható logisztikai szolgáltatásokat nyújtó, sokirányú tevékenységet folytató északi-tengeri-atlanti-óceáni „range” kikötök (Hamburgtól Le Havreig) hihetetlen vonzeröt gyakorolnak mélyen tagolt hinterlandjukra (Hamburg, Antwerpen és Rotterdam Magyarországra is), ami nemcsak hatalmas anyagi eröhöz, tỏkeakkumulációhoz vezetett, hanem oda is, hogy régiójuk az innovációban a top-on áll, hallatlanul széles spektrumú foglalkoztatást valósítanak meg. Környezeti szempontból viszont kétarcúak: hatalmas és látványos eröfeszítésekkel környezetvédelmi innovációk alkalmazásával, környezeti iparok telepítésével lényegesen javult az ökológiai állapotuk, azonban a rendkívüli méretü forgalom miatt az emisszió méretén ma már igen nehéz tovább javítani (pl. a közlekedési zaj mérséklése már csak a forgalom - gazdasági szempontból egyáltalán nem kívánatos csökkentésével volna elérhető).

A nagy kikötök (városaikkal együtt) igen erős koncentráló hatásukkal a térszerkezetben általában peremi/fókusz jellegű központokat, csomópontokat alkotnak, de egyes folyami kikötők erőösszpontosító szerepe is nagy lehet.

A hagyományos vasutak ma a versenyképességben meglehetösen szerény szerepet játszanak Európa nyugati felének régióiban. A gazdasági hatékonyságot kis mértékben segítik elö, a foglalkoztatási hatásaik sem a régiek: a 20. század eleji állapothoz képest egyharmadnyi-egyötödnyi létszámmal müködnek. Környezeti szempontból kétségtelenül az elönyeit látja a régió (különösen, ha nagy mértékben villamosított). Kelet-Közép- és Kelet-Európában a vasút súlya már jóval nagyobb, különösen a megfelelöen kiépített utakkal alig rendelkező, ráadásul ritka hálózatú észak- és kelet-oroszországi régiókban. A vasutak térszerkezeteket befolyásoló hatása ugyan a történelem folyamán és térségenkénti változatok szerint többféle módon érvényesült, azonban végső soron a termelési tényezöket összpontosító hatása lett a megha- 
tározó, elősegítve óriási termelöüzemek kialakulását. Nélküle nem alakulhattak volna ki sem a nagyvárosi, sem az ipari agglomerációk.

Valamennyi alágazat közül a csővezetékek képesek a leghatékonyabban és a legkörnyezetkímélöbb módon nagy távolságra továbbítani a folyékony és légnemü halmazállapotú szénhidrogéneket, valamint a közmüvek számára a vizet a nagy víznyerö forrásokból. Ugyancsak csővezetéken lehet eljuttatni a kőolajfinomítókból a termékeket a felhasználó piacra. Európa nyugati fele a kőolaj igényének túlnyomó részét tengerentúli importból szerezte be, így a nagy finomítók - kevés kivételtỏl eltekintve - a tengeri kikötőkben müködtek. Ennek olyan következménye lett, hogy az üzemanyag és fütőolaj a kikötőrégiókban volt a legolcsóbb, kedvezve a termékárakra érzékeny ipari és más (szolgáltatói, logisztikai) tevékenységek letelepedésének. Ugyanakkor a kontinens belsö régióiban a magasabb olajtermék árak kedvezötlenebbé tették a versenyképességet. Ezért az 1950-es években (az akkori Szén- és Acélszövetség ösztönzésére) sorra megépülttek a nagy kőolajfogadó kikötőkböl (pl. Marseilleből, Genováéból, Triesztből, Hamburgból, Rotterdamból) a szárazföld belső térségeibe vezető nagykapacitású olajvezetékek, továbbá felépülttek Franciaország, Németország és Ausztria területén a tengertől többszáz km távolságra az óriási finomítók. E folyamat eredménye a kőolajtermékek árának területi kiegyenlítődése lett. Ezzel megvalósult a szárazföld belsejében fekvö régiók esélyegyenlösége a fütöolaj- és üzemanyag költségek szempontjából. Így versenyképességüket azóta már nem rontja le a kőolajtermékek drágasága.

A létrejött új finomító kombinátok (egyoldalú férfi munkaerö igényükkel) összpontosított monostruktúrát teremtettek, a „pontgazdaság” szélsőséges modelljét leképezve, amelynek diverzifikálása, a többrétú gazdasági szerkezetre és nem utolsó sorban a női munkaerő foglalkoztatás megoldása érdekében a hatvanas-hetvenes évektől számos más iparág telepedett meg a finomítók közelében (pl. Ingolstadtban az Audi autógyár, majd elektronikai üzemek) - amelyek tovább növelték a telephely koncentrációt, de egyben e térségek versenyképességét is a hatékonyság szempontjából. Ellenben környezeti szempontból - a mégolyan kiváló emisszió csökkentỏ technológiák használata ellenére is - vitathatatlanul nem a legvonzóbb térségek, amely tényt a nagyfokú foglalkoztatás aligha tudja ellensúlyozni (Erdösi 2000b).

A kỏolajvezetékekkel szemben a földgázvezeték és a villamos távvezetékek már közel sem fejtenek ki komolyabb összpontosító hatást (az olyan megaméretü felhasználók kivételével, mint a gáztủzelésủ nagy erőmüvek, illetve az ,áramfaló” alumínium kohók stb.), sőt mind a gáz-, mind az áramszállító hálózatok többszörös szétágaztatásával, az egyes háztartási fogyasztókhoz való eljuttatásával többnyire kifejezetten a térbeli decentralizáció eszközei.

Az elöbbi alágazatokkal szemben a közúti közlekedés viszont a munka és lakóhelyek diszperz, szétszórt elhelyezkedésének, végsö soron a dekoncentrált térszerkezetnek kedvez.

Még a közepesen fejlett országok (így hazánk) régióira is jellemzö, hogy egy-két törpefalu, vagy falumaradvány és a szórványtelepülések nagy része kivételével szinte teljes körü a településállománynak a kiépített közúthálózathoz való csatlako- 
zása, és a menetrendszerü autóbusz-közlekedés is kiszolgálja a települések 97-98\%-át. Valamennyi alágazat közül az idöben és térben rugalmas közúti közlekedés a legnagyobb mértékben területfeltáró és decentralizációt elösegitö tulajdonságú. Az elöbbiekből fakadó kiemelkedően kedvező tulajdonsága, hogy átszállás, illetve átrakás nélkül lehetövé teszi mind belföldi, mind nemzetközi viszonylatban a megszakítás nélküli háztól-házig történö közlekedést és szállítást. Ha eltekintünk az externális költségeitől, a jelenlegi gazdasági szabályozók mellett gazdasági értelemben ez a leghatékonyabb közlekedési alágazat, amely fajlagosan is nagyobb munkaerö igényü a vasútnál. Ugyanakkor a gépjármủvek az emisszió (lég- és talajszennyezödés) tekintetében messze megelőzik a többi közlekedési eszközt, így a versenyképesség harmadik eleme, a környezet védelme terén a legkifogásolhatóbbak.

A közúti közlekedés magisztráléi, az autópályák és gyorsforgalmi utak viszont már - átmenetet képezve a hagyományos és az új közlekedési infrastruktúrák között - az 1960-as évek óta egyre erỏsebb szívóhatást gyakorolnak a környezetükre a mellé települt munkahelyek és szolgáltatóhelyek révén. A legtöbb autópálya ma már gazdasági-települési növekedési tengelyt, sőt folyosót jelenít meg a térben. Ezek alapján átmeneti helyet foglalnak el a hagyományos és az új (nagyteljesítményü) közlekedési infrastruktúrák között.

\section{Az új, nagy hatékonyságú közlekedési eszközök hatásai}

Nagysebességü vasutak

A nagysebességü ( $200 \mathrm{~km} / \mathrm{h}$ feletti közlekedést lehetővé tevő) vasutak ma Nyugat-, Dél- és Észak-Európában még összesen csak mintegy 20 régiót kedvezményeznek jelenlétükkel. Legkiterjedtebb a hálózatuk Franciaországban, majd Németországban, míg Olaszországban, Svédországban, Spanyolországban és Belgiumban csupán egy-egy vonallal vannak jelen.

A TGV, ICE, AVE, Direttissima, X2000, Thalys a repülögép mellett a második leggyorsabb közlekedési eszköz, amely kényelmi és utasszolgáltatási szempontból több tekintetben felül is múlja a légi közlekedést. (Az egyelöre távolsági közforgalmi célokra nem kiépített mágnesvasút $500 \mathrm{~km} / \mathrm{h}$ feletti sebességre is képes.) A nagysebességú pályák általában teljesen új nyomvonalon, magas müszaki követelményeket kielégítő módon épülnek, ezért rendkívül költséges infrastruktúrák. Építésük magas technológiai szinten történik, ezért az értékükhöz képest alacsony az élömunka igényük, még az alépítmény és mütárgy építések is erősen gépesítettek. Üzemelésük munkaerőigénye is kevés a magas fokú automatizáltság okán. A fedélzeti catering és az állomásokon nyújtott kvalifikált szolgáltatások csupán marginális plusz tételek a foglalkoztatásban.

Annál kedvezöbb tulajdonságúak a szupervonatok a hatékonyság és a körmyezet szempontjából. Igaz, hogy a gyors és kényelmes (menet közben a szellemi munkavégzést is lehetővé tevő) eljutás, az ütemezett ingaközlekedés általi nagy kínálati gyakoriság elönyét totálisan csak azok a jelentösebb városok élvezhetik, amelyek állomásán e vonatok megállnak. Éppen az általuk kiszolgált lakosság számának 
növelése érdekében az egyes járatok különbözö (alternatív) megállórend változatok szerint közlekednek, de így is csak a hagyományos vasutak állomás állományához képest egytizednyi-egyhuszadnyi helyen, 80-150 km-enként állnak meg, legföbb előnyük, a rövid menetidó tartása és az energiafogyasztás minimalizálása érdekében. A rövid menetidőt ugyan magasabb árért élvezheti az utas, de ez nem igazán visszatartó tényezö a módosabb közönség körében. Üzletembereken kívül a jobban fizetett alkalmazottak már napi ingázásra is igénybe veszik. Így e közlekedési eszköz egyes nagyvárosok (pl. Hannover, Párizs, Lille) bejárási (munkaerő) vonzáskörzetét bizonyos irányokban akár $120-200$ km-re is tágíthatja a hagyományos 20-60 km-rel szemben.

A nagysebességủ pályák melletti és mögötti, a szupervonatok állomásaitól távolabb fekvő települések kedvezőtlenebb elérhetőségi helyzetén csak jól működő, pontos kiegészítő/ráhordó közlekedéssel lehet bizonyos mértékig segíteni, de egyenértékűséget természetesen nem lehet elérni.

Egyelőre a legtöbb országban kizárólag távolsági (kisebb részben nemzetközi) utas- és postaszállitásra használják a nagysebességủ vasutakat. Hatékonyságuk növelhetôn, ha kvázi nagysebességgel $(160 \mathrm{~km} / \mathrm{h})$ korszerü áruszálító/konténerszállító irányvonatokat közlekedtetnek rajtuk. (Éjszaka, amikor szünetel a személyszállittás.) Ilyen módon a pálya kapacitás nagyobb fokú kihasználtságával elért jobb üzemi hatékonyságon kívül régió szinten is javul a hatékonyság azzal, hogy e közlekedési eszköz nemcsak a lakosságot, hanem a termelést, a tágabb értelemben vett gazdaságot is közvetlenül szolgálja.

A kizárólag villamos vontatású nagysebességủ vasutak a régiók versenyképességét a legegyértelmübben a környezetvédelemmel, konkrétan az emisszió elhanyagolhatóan alacsony szintre csökkentésével szolgálják. Kétségtelen viszont, hogy egyelőre magasabb a zajszintjük a hagyományos vasutakhoz képest, ezért a lakott területekhez közeli szakaszokat zajvédő falakkal veszik közre.

Az eddigi (egy-két évtizedes) tapasztalatok szerint a nagysebességü vasutakkal kiszolgált városoknak az adott ország többi városához képest javult a gazdaságikulturális poziciója, kedvezóbb volt fejlódési dinamikájuk. E felismerés indította a kedvezményezetteket Franciaországban, hogy létrehozzák a „TGV-Városok Szövetségét", amely fejlődőképes városok egyfajta nagy image-hordozó elit szervezete. E példát már további, más országokbeli, hasonló presztízsủ városok követték, sőt nemzetközi szervezetük is megalakult (Erdösi 2000b).

A nagysebességủ vasutak (a velük egyirányú többsávos, tranzitforgalmat is hordozó nagykapacitású autópályákkal együtt) olyan magisztrális közlekedési folyosókat képeznek, amelyek a mögöttes területekre gyakorolt óriási szívóerejükkel rendkívül erős lineáris koncentrációhoz vezetnek és a térszerkezet markáns elemeivé válnak. Amennyiben irányuk jelentősen eltér a korábbi (hagyományos) térszerkezeti vonalaktól, képesek látványos módon módosítani, új textúrájúvá strukturálni az ország térszerkezetét. Ezzel nemcsak új távolsági forgalom áramlási viszonylatok jöhetnek létre, hanem növekszenek a régiók közötti különbségek is a versenyképesség tekintetében (Erdösi 1998a). 


\section{Légi közlekedés}

A légi közlekedést ki kell emelni a modal splitből, mert a régiók versenyképességének alakulásában már eddig is, de méginkább a jövőben rendkívuil rangos tényezơvé lépett (lép) elö.

Nagy általánosságban megfogalmazható, hogy az olyan, legalább gyenge közepes népsürüségü (min. 50 fö $/ \mathrm{km}^{2}$ ) és laksürüségü, hagyományos és az átlagoshoz legalább közelítő sürüségủ vasút- és úthálózattal rendelkező régiókban, ahol az össz interregionális utasszállítás legalább $5 \%$-a, a nemzetközi utasszállításnak pedig legalább a 25\%-a, továbbá a 10 Euro/kg-nál nagyobb fajlagos értékủ áruk interregionális szállításának $2 \%$-a, a nemzetközieknek pedig a 30\%-a légi úton történik, a légi közlekedés hatékonyan képes hozzájárulni az adott régió versenyképességéhez (Erdösi 1998b). Ahol az előbbi értékek 1,5-2,0-szeresével még nagyobb a súlya a légi közlekedésnek, ott a versenyképességben az egyik döntő tényezővé lép elő.

A légi áruszállitás nagyon eltérő adottságú régiókban is a gazdaság nélkülözhetetlen tényezőjévé válik:

- mindenekelött a kifejezetten ritkán lakott térségekben, ahol valamilyen országos fontosságú gazdasági aktivitás modernkori feltétele megtalálható, mivel a földi közlekedés építése vagy lehetetlen (természeti nehézségek miatt), vagy elviselhetetlenül drága. Ilyenek Kanada és Szibéria északi régió, ahol urán, ötvöző fém és ritkafém, valamint arany és gyémánt bányászat folyt, illetve folyik, ahol a bányák fajlagosan alacsony értékü felszereléssel, sỏt nagy méretủ gépekkel, élelmiszerrel és más fogyasztási cikkekkel való ellátása - legalábbis a kezdeti időszakban - légi úton történt.

Ezekben az esetekben tehát nem a hagyományos közlekedésgazdasági gondolkodás, hanem másfajta, de így is piackonform racionalitás érvényesül a modal splitnek a szállítási kereslethez való alakításában, azzal, hogy csupa olyan árut kell szállítani, amelynek súlyegységnyi ára szélső esetekben alacsonyabb lehet a szállítási költségnél, azonban nélkülözhetetlensége miatt „bármi áron" meg kell történjen a helyszínre eljuttatása abban a reményben, hogy a magas ráfordítások ésszerủ időn belül megtérülnek az akár stratégiailag is kiemelkedő jelentőségü, nagy értékủ outputból.

A nemzetgazdaságok vérkeringésében, illetve a világkereskedelemben lényegében a közlekedésileg nem feltárt „fehér foltokat, amelyek korábban mintegy kívül maradtak a versengỏ régiók köréböl, a légi közlekedés hozhatja versenyhelyzetbe, emelheti be a versengők közé.

- A másik régiótípus, amelynek versenyképessé válásában a légi szállításnak majdnem hogy meghatározó, de legalábbis nagy szerepe van az, amelynek termelési szerkezetében elökelö helyet foglalnak el a fajlagosan igen nagy értékü olyan speciális termékek, amelyek

$\Rightarrow$ egyrészt „elbírják” a légi szállítás drágaságát, és együttes repülögépes eljuttatásuk biztonságosabb, mint földi közlekedési eszközökkel (drágakövek, mikroelektronikai alkatrészek és drága eszközök, müszerek stb.), 
Gondolatok a közlekedés szerepéröl a régiók/városok versenyképességének alakulásában. Tér és Társadalom, 16. 2002. 1. 135-159. p.

$\Rightarrow$ másrészt a megrendelökhöz való eljuttatása a lehető legrövidebb idő alatt kell, hogy megtörténjen a gyors erkölcsi amortizáció miatt (napi- és hetilapok, aktuális gazdasági híreket, tőzsdei információkat, értékeléseket és tanácsokat, továbbá rendezvény-müsorokat tartalmazó kiadványok, különféle katalógusok stb.), vagy a sürgössége miatt (alkatrészek, amelyek nélkül gépeket, üzemeket kell leállítani, tervdokumentációk, amelyek alapján lehet megkezdeni vagy folytatni az építő, illetve más termelési feladatot).

$\Rightarrow$ Ha nagy országról van szó (USA, Kanada, Oroszország, Kína stb.), az elöbbi interakciók nagy része végbemehet belföldi (interregionális, esetleg intraregionális) viszonylatokban, azonban Európára jobbára az jel. lemzö, hogy az ismertetett hagyományos motivációjú légi szállitás nemzetközi viszonylatokban megy végbe és a gazdaság globalizálódásával, valamint a területi munkamegosztás, szakosodás koncentrációs hatásaival egyre nagyobb távolságokra, mind több destináció felé. A versenyképesség így nagyjából annak arányában növekszik, mennél nagyobb és lukrativabb értékesitési és beszerzési areálra képes szert tenni az adott régió a globális piacon, mivel ez nemcsak a termelés volumenét befolyásolja kedvezöen, hanem a hatékonyságot a legnagyobb mértékben meghatározó technológia szintet is a nemzetközi transzfer segítségével.

- A harmadik régiótípus, ahol a versenyképességnek igencsak conditio sine qua nonja a légi közlekedés, a világvárosi agglomeráció, a tömeges és igen sokrétủ távolsági légi közlekedési és szállítási igényével. A diverzifikált gazdaság (termelés és szolgáltatások), a kereskedelem, a kulturális funkció és a lakosság szabadidős mobilitása együttesen indukál kiemelkedő légi forgalmat, a légi közlekedés kivételesen jó adottságai akcellerátornak bizonyulnak további funkciók vonzásával, a meglévők erősítésével a megapoliszok és régiójuk további pozíciójavulásához. Erre nemcsak a világgazdaság (ezen belül a globális pénzpiac) „háromlábú széke": New York, London és Tokió, hanem pl. Chicago, Atlanta, Párizs, Los Angeles/San Diego agglomerációja is jó példát szolgáltat.

- Az utóbbi évtizedekben a hub and spoke forgalomszervezés eredményeként olyan izolált óriásvárosok (illetve „városállamok”) váltak a nemzetközi légi szállítások tranzit/transzfer csomópontjaivá, amelyekben az egyébként nem jelentéktelen célforgalmat messze felülmúlja a közvetítö, „,a szálakat összekötö” funkció. Ilyenek mindenekelött Szingapúr és Hongkong (utóbbi ezen funkcióját a Kínai Népköztársasághoz való visszacsatolása alig érintette).

- Földrészre, vagy több kontinensre kiterjedô vonzással rendelkezö, nagy embertömegeket vonzó vallási és kulturális központok az igényükre kiépült légi közlekedési infrastruktúrájuk révén régiójuk versenyképességének nem felejthető tényezỏjévé váltak.

A folyamatosan, vagy az év meghatározott időszakában rendszeresen látogatott vallási központokat kiszolgáló nemzetközi repülöterek müködése közvetle- 
nül vagy indirekt módon közrejátszhat egy régió gazdasági/szellemi fejlödésében, végsỏ soron versenyképességében. Ahol e központok egyben fỏvárosok is (pl. Róma, Jeruzsálem), ott természetesen az államigazgatási és más központi szerepkörökkel közösen, azoktól nehezen elkülöníthetỏen képez fejlesztő tényezỏt a vallási világközpont funkció, illetve az azt szolgáló repülỏtér.

PI. Rómában, a katolikus vallás globális kompetenciájú centrumában a 2000. szentév rendezvényei több millió föt elérỏ látogatóinak közlekedését megkönnyítendỏ nemcsak a helyi/elővárosi közlekedést - beleértve az agglomerációs gyorsforgalmi úthálózatot - fejlesztették és a pályaudvarokat bővítették, hanem a repülöterek kapacitását is nagyban növelték. Nyilvánvaló, hogy e beruházások a következő években tovább erösítik Róma „világi” turisztikai vonzerejét, ezzel javítják pozícióját a gazdaságilag erősebb Milánóval szembeni versenyben.

Az izraeli Ben Gurion nemzetközi repülötér évi 10-12 millió utast elérỏ forgalmának bő egynegyedét azok a „vallási turisták”, zarándokok teszik ki, akik mindenekelőtt Jeruzsálem, másodsorban Betlehem és Názáret megtekintéséért utaznak az országba. Az általuk keltett légi közlekedés és az azt kiegészítő földi közlekedés nem elhanyagolható tényezöje a Tel Aviv-Jeruzsálem korridor menti régiók kiemelkedö versenyképességének, aminél természetesen nem tekinthetünk el (az ugyancsak légi közlekedés által kiszolgált) ottani nagy output értéket reprezentáló gyémántcsiszoló, ékszerkészítỏ ipar hozzájárulásától sem.

A spanyolországi Santiago de Compostella nemzetközi búcsújáró helyként Dél-Amerikát is magában foglaló vonzáskörrel rendelkezik. Földrajzi fekvése folytán elérésének adekvát eszköze a repülőgép. Az 1970-es években a közelében épült korszerü repülőtér lehetővé teszi, hogy nagy gépes non stop interkontinentális charterjáratokat is fogadjon. Az utóbbi idöben az évente Ferihegy forgalmának 2/3-át bonyolító repülőtér nemcsak a város, hanem a spanyolországi viszonylatban gazdaságilag csak közepesen fejlett régiója (Galícia tartomány) esélyeit némileg növeli a régiók közötti versenyben azzal, hogy a lényegében a vallási turizmus érdekében létesített közlekedési infrastruktúra a világi turizmust, de ezen túlmenően a szélsőségesen peremhelyzetủ régió gazdasági szerkezetváltását is elösegíti.

Hasonló megállapítások érvényesek a dél-franciaországi Lourdesra, amelynek a közeli Tardes várossal közös, nemzetközi forgalmat is bonyolító repülőtere a Bearn régió pozícióját javítja, mint ahogyan a Liesseux búcsújáróhelyet évente látogató több millió külföldi utazását be kellett kalkulálni Caen és Cherburg normandiai repülőterek kapacitásának tervezésébe.

- A mohamedán világ leglátogatottabb zarándokhelye Mekka. E várost hosszú időn keresztül csak idöigényes utazással lehetett elérni. (A legközelebbi Vörös-tengeri kikötökig hajóval, a szárazföldön tevekaravánokkal, majd a part közeli Hedzsasz-vasúton Medináig utaztak.) Az utóbbi időben viszont a Délkelet-Ázsiában és a Fekete-Afrikában is rendkívül gyorsan terjedó iszlám hívei már túlnyomórészt légi úton közelítik meg Mekkát. Mivel a szent város 
Gondolatok a közlekedés szerepéröl a régiók/városok versenyképességének alakulásában. Tér és Társadalom, 16. 2002. 1. 135-159. p.

közvetlen közelében megtiltották repülötér létesítését, az alig 100 km-re fekvő Vörös-tengeri nagyváros, Jeddah mellett épült meg a Ferihegynél másfélszer/kétszer forgalmasabb nemzetközi repülötér, ahonnét többsávos föúton folytathatják útjukat a zarándokok Mekkába.

\section{Hozzájárulhatnak-e a nagy hidak és alagutak a régiók versenyképességéhez?}

A szárazföldi (közúti és vasúti) közlekedés folyamatosságát lehetővé tevő, széles vizeken átívelő hidak, illetve természetes választóvonal szerepet betöltő hegységeken áthatoló sok kilométer hosszú alagutak sokkal többek, mint csupán mütárgyak, azaz müszaki létesítmények.

Városok vonatkozásában a hidak akkor válhatnak a versenyképességet kedvezöen befolyásoló tényezővé,

- ha a folyóvíz, tengeröböl által elválasztott városrészek között teremtenek (a közlekedési költségeket csökkentő, az eljutási időt rövidítő) intracity jellegủ összeköttetéseket és az így növelt belsö kohézió, illetve a városrészenként specializálódott tevékenységek közötti interakciók akadálytalanná válása városi szinten szinergiákat hoz létre (pl. Budapesten, Szegeden, Londonban, Prágában);

- ha önálló igazgatási státusú ikervárosok között ad lehetöséget a komparativ elönyök érvényesülésére (pl. a kifejezetten ipari profilú német Ludwigshafen és a nemzetközi igazgatási-kultúrváros Mannheim közötti Rajna-hidak, vagy az USA-beli St.Paul malomipari város és Minneapolis közötti Mississippi hidak, de akár a Tisza-híd által lehetövé vált szimbiózis Csongrád és Szentes között). A felsorolt valamennyi esetben a kölcsönös munkaerỏ ingázás, a szellemi munka kapacitások ésszerú kihasználása, a termelés gazdaságossági küszöb feletti nagyságrendben való kialakításának esélye (economies of scale) stb. mind a hatékonyságban, mind a foglalkoztatásban tényleges elönyökhöz segítheti az érintett településeket az azonos országhoz tartozó települések kòzötti híd által.

Az előbbiekben állítottak érvényesek az egy régión belüli kardinális kapesolatokat hordozó hidakra is. Erre a legeklatánsabb példát a Szajna torkolati, az utóbbi évtizedekben épített hidak (Brotonne, Tancervillei és föként a tengeröböl-közeli Pont Normandie) nyújtják, amelyek Normandia északi és délnyugati részét kötik össze. Korábban ugyanis a nagymúltú Normandia tartományt keresztülszelö Szajnán át csak a torkolattól távoli (közel 100 km-re levő) Rouen városnál lehetett hídon átkelni, Rouen alatt csak kompokkal. Ha nem is a hídépítés volt a fö tényezője Normandia látványos fejlődésének, versenyképességbeli pozíciója javulásának, de mindenképpen az egyik komponense lehetett a sikernek, többek között a tartományon belüli idegenforgalom, továbbá a nemzetközi tranzitforgalom élénkülése folytán. 
Még nagyobb hozama lehet a versenyképesség szempontjából a határfolyókon, vagy országokat elválasztó tengerszoroson át létesített hidaknak, illetve óriás híd/alagút komplexumnak, amelyek révén binacionális gazdasági régiók alakulhatnak ki.

Pl. 1918 elött a mai szlovákiai Komarno-nak a jobb parti Kiskomárom (a mai magyarországi Komárom) városrész tartozéka volt, azonban Trianon óta önálló életet él a két város. A Duna-híd adta lehetőség azonban elvezethet egyfajta eurórégió létrejöttéhez, amely a térség versenyképességére nyilvánvalóan csak jó hatással lehet. Az Al-Duna két partján egymással szembenéző városok, a bulgáriai Rusze és a romániai Giurgiu közötti híd teremtette kapcsolat egyelöre inkább az egyéni üzletelést, a bevásárlóturizmust generálja, de potenciál lehet egy-két évtizeden belül a megtalált komparatív előnyökre alapozó közös gazdasági régió kialakulásához.

Az előbbi példákhoz képest nagyságrendekkel jelentősebb és a nem adminisztratív eszközökkel ösztönzött, hanem piacgazdasági spontán folyamatok által generált szerves térintegráció tanúi lehetünk a Svédországot Dániával az Öresundon át öszszekötő európai jelentőségü $18 \mathrm{~km}$-es híd/alagút komplexumnál. A dán föváros, Koppenhága és a szemközti svéd Malmö a nagytejesítményü (bár drága) infrastruktúra hatására gazdasági és kulturális/oktatási komplexummá válik, amely elveszti nemzeti jellegét - oly annyira, ahol ún. „svédán” nyelven kommunikálnak, oktatnak a kölcsönösen látogatott egyetemeken. Minden jel arra mutat, hogy (Berlinen kívül) „Koppenmalmö" régió lesz Európa északi felének legnagyobb innovációs központja, illetve az egyik top-sikerrégiója.

A Nagy-Britannia és Franciaország közötti félszáz km-es Csatorna- (Európa-) alagúthoz összefutó korridorok partközeli összekötegelödésének térségében kivételes méretü logisztikai és termelő telephely beruházások valósultak meg mind a két országban, amelyek éveken belül alaposan elöresorolták Kent, illetve Pas de Calais és Flandre régiók versenyképességét.

\section{A közlekedés távközlés általi támogatottságának, illetve helyettesíthe- töségének hatása a versenyképességre}

A közlekedés minőségét, hatékonyságát már ma is és a jövöben még inkább befolyásolja, hogy mennyire alkalmazzák a jármüvek mozgásvonalát optimalizáló (ezzel forgalmi dugók elkerülését szolgáló), a fuvar kapacitások, parkolóhelyek kihasználását, vagyonvédelmét, biztonságát stb. segítö távközlésiltelematikai eszközöket, illetve szolgáltatásokat, amelyek végsỏ soron komplex city- és régió-logisztikai rendszerek kialakításához vezethetnek.

A közlekedést támogató telematikai rendszerek azzal javítják a régió versenyképességét, hogy

- csökken a járművek improduktív ideje az út során, áru és utas hamarabb eléri a destinációt, javul a just in tíme rendszer megbízhatósága (nem kell hosszabb rátartási időkkel számolni),

- az egyenletesebb jármüsebességgel mérséklödik az emisszió. 
Jóval bonyolultabb kérdés, hogy a távközlés/telematika széles körü alkalmazásával lehet-e helyettesíteni, csökkenteni a közlekedési forgalmat.

Elvileg a távközlésben és az informatikai/telematikai technológiákban komoly, közlekedést helyettesítö potenciál rejlik, különösen a távmunka révén. A lakáson számítógép, fax, internetcsatlakozás, mobiltelefon, esetleg videokonferencia igénybevételével nemcsak adminisztrációs rutinmunkák végezhetők (pl. számlázás a közmủ fogyasztóknak, biztosítási dỉj kiszabás és nyilvántartás, bérszámfejtés stb.), hanem kvalifikáltabb munkák is (pl. fordítás, rendszerszervezés, müszaki tervezés, koncepciók kidolgozása). Külföldi példák bizonyítják, hogy akár még szakminiszterek is képesek ellátni a feladatukat oly módon, hogy hetente csak egyszer utaznak be a többszáz km-re levỏ minisztériumba, míg a többi munkanapon otthonról látják el felelősségteljes és sokirányú feladatukat.

A távmunka színhelye a saját lakáson kívül a közeli teleház is lehet. Az utóbbi megoldás különösen térségünkben jöhet számításba, mivel így megtakaríthatók a „telemunkás” otthoni költséges távközlési/informatikai beruházásai.

Kétségtelen, hogy a távmunka elterjedése a munkába járással, ingázással kapcsolatos közlekedés akár 30-40\%-ának megtakarításához is vezethet egy-két évtizeden belül. Néhány éve még nagy reményeket füztek a telebanking és teleshopping szolgáltatásokhoz, sőt a telemedicinához. Bár hazánkban is van lehetőség a banki ügyletek személyes megjelenés nélküli intézésére, több helyen még a távvásárlásra is csomagküldő szolgálattal, és kísérletképpen videokonferencia segítségével Budapesten belül távgyógyításra is sor került már, egyelőre a távszolgáltatások csak elhanyagolható részét teszik ki a hagyományos, utazással járó face to face jellegüeknek, és nem sok jele van annak, hogy a közeljövőben szélesebb körben elterjednek.

Ezzel szemben az e tekintetben élen járó fejlettebb országokbeli tapasztalatok szerint a távmunka és távszolgáltatások segítségével megtakarított munkahelyre utazásokat, illetve az így megtakarított időt korunk legattraktívabb tevékenysége, a szabadidő eltöltésének legváltozatosabb módjaira fordítják, így az össz mobilitás nem csökken, csak a funkcionális szerkezete változik meg, sőt a mind magasabb szintü gépkocsi-ellátottsággal a közúti forgalom szakadatlanul tovább növekszik.

Mindezekböl az a következtetés vonható le, hogy az új információs/telekommunikációs technikák és szolgáltatások elterjedése lényeges változást nem hoz a környezetet ma a közepesen és magasan fejlett régiókban legerösebben károsító közúti forgalomban. Vagyis e tényezö által a régiók ökológiai állapotában sem várhatók olyan kedvező változások, amelyek a versenyképességet képesek javítani környezeti téren.

Az viszont kétségtelen, hogy az $I+K$ ellátottság mértéke szinte kézzelfoghatóan megmutatkozik a régió gazdaságának hatékonyságában. A publikus üzleti/ müszaki/szervezeti/társadalmi/politikai információkhoz való hozzájutásnak az erre alkalmas készülékek és szolgáltatások mennyisége, fajlagos ellátottsága tekintetében meglevő mennyiségi különbségeknek ma már nincs különösebb gyakorlati jelentősége az ủzleti szférában, olyan alapon, hogy minden vállalkozónak van mobiltelefonja, a legtöbbnek számítógépe, viszont a számítógépben rejlö információ- 
szerzés lehetőségét a képzettség már erősen befolyásolja, ahogyan a legújabb távközlési innovációkhoz való hozzáférés is átmenetileg jelentős differenciáló tényező lehet.

Magyarországon a régiók hatékonyságát és versenyképességét befolyásoló tényezők közül egyszerủen kimaradtak a fejlett országokban elterjedt olyan szenzációs létesítmények, mint

- a teleportok,

- az információs városok,

- a technopoliszok és

- a médiavárosok stb.

amelyek pl. Angliában, Franciaországban, Japánban, az USA-ban és még jó néhány országban régiójuk gazdasági/társadalmi állapotát létrejöttükkel igencsak megváltoztatták, és a legfeltünőbb szereplőivé váltak a régiók versenyképesség terén végbement differenciálódásának.

Az internet továbbfejlesztés alatt álló újabb változata, a néhány éven belül piacképes harmadik generációs mobiltelefon, az $\mathrm{I}+\mathrm{K}$ technológiák és szolgáltatások multimédia felé való eltolódása, a nagy hatékonyságú médiumok otthonról, a legegyszerübb munkahelyröl való elérhetösége révén erösen devalválódhatnak a jövöben a profitorientált teleportok (nem jelent már elönyt a globális vételt lehetővé tevö ,antennafarmjuk”), mint ahogyan több tekintetben az olyan innovációs koncentrációk, mint az információs városok is okafogyottakká válhatnak. A telekommunikáció a szolgáltatástechnológiáját tekintve egyre személyesebb természetủ, a privát szféra eszközévé válik, még akkor is, ha közvetlenül vagy közvetetten üzleti célokat szolgál.

\section{Összefoglalás}

A közlekedés (mint az egyik alapfeltétel) fejlesztése a következö folyamatokkal képes a régiók versenyképességének rangos tényezőjévé válni:

I) Növeli a gazdasági hatékonyságot

- a globális, illetve a nemzetközi gazdaságba való integrálódást elősegítő jobb (gyorsabb/nagyobb teljesítményü/üzemi szinten olcsóbb) külső (nemzetközi/interregionális) szállítási kapcsolatokkal, beleértve az energiaellátás külföldi vagy nagy távolságra levő hazai forrásokból való megoldását is;

- a régión belüli gazdasági és más jellegủ kohéziót erősíti, megkönnyíti a régióközpont intézményeinek elérését a régió különféle térségeiböl, lehetővé teszi az ütemezett szálítást a vidéki kibocsátóhelyek és a régió központbeli (magtérségi) feldolgozóhelyek között.

II) Javítja a foglalkoztatást, nem annyira közvetlen módon, azaz a közlekedésböl élök számának növelésével, mint inkább a jobb közlekedési viszonyok ha- 
tására a befektetök számára vonzóbbá váló területen javuló foglalkoztatási viszonyok, a vidéki munkaerő számára jobb ingázási feltételek biztosítása által.

III) Jobbá teszi az életkörülményeket, hozzájárul az életminőség javításához, a „kultúrafogyasztáshoz” kedvezőbb feltételeket teremt, megfelelő müszaki fejlesztés esetén összességében szinten tartja vagy éppen mérsékli a közlekedés káros szerepét a régió ökológiai állapotának alakulásában.

\section{Jegyzet}

1 Az egyszerủség és a markirozás lehetősége érdekében az úthálózatból csupán az autópályák és gyorsforgalmi utak építését vontuk be az értékelésbe.

\section{Irodalom}

Erdősi F. (1991) Kommunikáció és térszerkezet. Területi és telepủlési kutatások 7. Akadémiai Kiadó, Budapest.

Erdősi F. (1992) Telematika. Távközlési Könyvkiadó, Budapest.

Erdősi F. (1998a) A transz- és páneurópai hálózatok. - Balogh A.-Papp G. (szerk.) Magyarország az. európai regionális együttmüködésben. MTA Regionális Kutatások Központja - Magyar Külügyi Intézet, Pécs-Budapest. 51-75. o.

Erdősi F. (1998b) A légi közlekedés földrajza, légi közlekedéspolitika. - MALÉV, Budapest.

Erdősi F. (2000a) Egy fikciótól a megvalósulásig: a regionális kỏzlekedés. - Horváth Gy. (szerk.) A régiók szerepe a bővülő Európai Unióban. MTA Regionális Kutatások Központja, Pécs. 174-189. 0.

Erdósi F. (2000b) Európa közlekedése és a regionális fejlödés. Dialóg Campus, Budapest-Pécs.

Erdősi F. (2000c) A kommunikáció szerepe a terület-és településfejlödésben. Területfejlesztési Szakkönyvek. VÁTI, Budapest.

Lengyel 1. (2000) A regionális versenyképességról. - Közgazdasági Szemle. December. 962-987. o.

Lengyel I. (2002) Regionális versenyképesség és infrastrukturra. Kézirat.

Lengyel I.-Deák Sz. (2001) A magyar régiók és települések versenyképessége az európai gazdasági térben (elméleti és fogalmi háttér, fóbb irányzatok). Kézirat. Szegedi Tudományegyetem Gazdaságtudományi Kar, Regionális és Alkalmazott Gazdaságtani Tanszék, Szeged.

Porter, M.E. (2000) Location, Competention and Economic Development: Local Clusters in a Global Economy. - Economic Development Quaterley. 1. 15-34. o. 